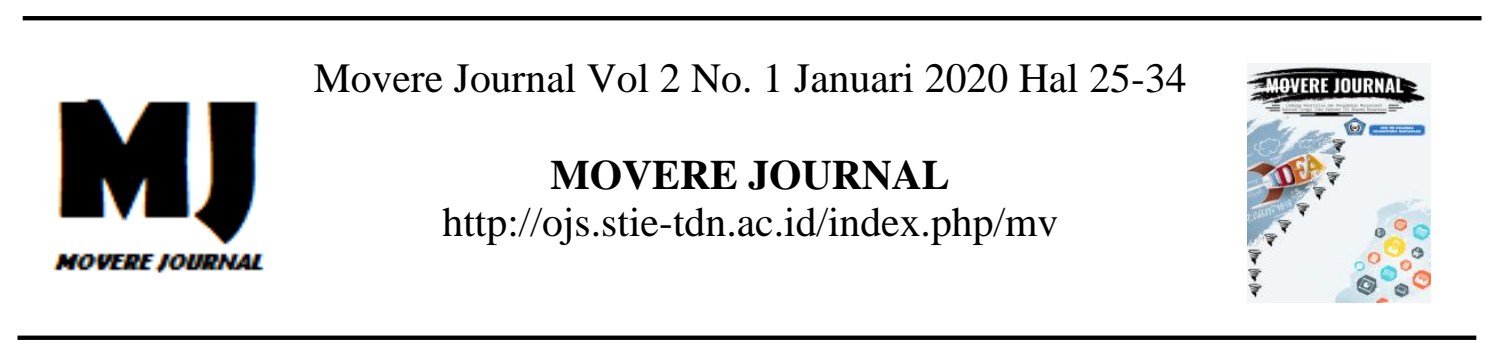

\title{
PENGARUH PENGGUNAAN MOBILE BANKING SMARTPHONE TERHADAP KEPUASAN NASABAH PADA PT. BANK NEGARA INDONESIA (PERSERO), TBK KANTOR CABANG MAMUJU
}

\author{
Iwan Adinugroho \\ STIE Muhammadiyah Mamuju
}

\begin{abstract}
Abstrak: Penelitian ini bertujuan untuk mengetahui pengaruh variabel penggunaan Mobile Banking secara simultan, untuk mengetahui pengaruh variabel penggunaan Mobile Banking secara parsial, dan untuk mengetahui variabel dari penggunaan Mobile Banking yang memiliki pengaruh dominan terhadap kepuasan nasabah. Variabel-variabel dalam penelitian ini adalah kebebasan, kesenangan, dan keamanan sebagai variabel bebas dan kepuasan nasabah sebagai variabel terikat. Analisis data yang digunakan adalah analisis deskriptif, analisis uji asumsi klasik, analisis regresi linear berganda dan analisis regresi parsial. Sampel yang diambil berjumlah 80 nasabah. Variabel kebebasan, variabel kesenangan dan variabel keamanan terbukti berpengaruh secara simultan terhadap variabel kepuasan nasabah. Variabel kebebasan, variabel kesenangan dan variabel keamanan terbukti berpengaruh secara parsial terhadap variabel kepuasan nasabah. Variabel kebebasan memiliki pengaruh yang dominan terhadap kepuasan nasabah. Kebebasan memang merupakan yang paling penting dalam Mobile Banking karena dapat memudahkan nasabah berinteraksi dengan bank, Fasilitas Mobile Banking yang dapat di akses melalui Smartphone dapat mempercepat transaksi perbankan, dan Mobile Banking dapat digunakan untuk transaksi perbankan yang tersedia.
\end{abstract}

Keyword: Kebebasan, Kesenangan, Keamanan, Kepuasan Nasabah

\section{PENDAHULUAN}

Teknologi adalah ilmu pengetahuan yang membantu kelangsungan hidup manusia, dan membantu memberi rasa nyaman, dan aman. Teknologi dibuat untuk mempermudah kerja manusia. Perkembangan teknologi semakin lama semakin meningkat pesat, di lihat dari banyaknya kegiatan yang di lakukan oleh manusia setiap harinya. Banyaknya pengguna internet di Indonesia tentu tidak dapat dipungkiri juga mendorong dunia bisnis untuk lebih maju dan berkembang. Internet menjadi media dalam melakukan transaksi penjualan dan pembelian.
Selain itu internet menjadi media untuk mencari informasi dan bertukar informasi. Teknologi informasi juga mendorong dunia perbankan untuk ikut andil dalam memanfaatkan internet (Rahayu, 2015).

Perubahan teknologi informasi yang berkembang sangat cepat ini direspon oleh perusahaan-perusahaan maupun dunia perbankan dengan memberikan pelayanan kemudahan akses informasi dengan kliennya maupun menghubungkan bank dengan nasabahnya dengan cara pengaplikasian teknologi informasi canggih, salah satu pihak yang sangat mengikuti perkembangan teknologi informasi adalah dunia perbankan (C) 2020 STIE TDN. All rights reserved 
(Arthana dan Rukhviyanti, 2015). Sekarang nasabah juga diajarkan untuk tidak lagi antri di bank (konvensional) nasabah bisa transaksi di echannel seperti ATM, CDM, CRM, EDC, dll disisi lain, bank akan diuntungkan dengan fee based income akibat transaksi tersebut. Salah satunya PT. Bank Negara Indonesia(Persero)Tbk sebagai sebuah perusahaan perseroan yang memiliki layanan e-channel tersebut. Layanan E-Channel adalah alat komunikasi yang digunakan untuk mempermudah perbankan dalam melayani nasabah atau sebaliknya. EChannel terdiri dari ATM, CDM, CRM, EDC, Mobile Banking.

Dalam hal ini, peneliti akan mengambil salah satu dari E-Channel tersebut yaitu Mobile Banking (BNI, 2018). Mobile Banking merupakan salah satu layanan informasi perbankan via wireless paling baru yang ditawarkan pihak bank dengan menggunakan teknologi handphone untuk mendukung kelancaran dan kemudahan kegiatan perbankan (Arthana dan Rukhviyanti, 2015). Fasilitas mobile banking dapat menjawab tuntutan nasabah yang menginginkan layanan cepat, aman, nyaman, murah, dan tersedia setiap saat (24 jam non-stop), serta dapat diakses dari mana saja, cukup melalui telepon seluler (Rahayu, 2015).

PT. Bank Negara Indonesia (Persero), Tbk Cabang Mamuju adalah salah satu bank BUMN yang sudah menerapkan layanan e-banking yang lengkap sebagai fasilitas pelayanan untuk nasabahnya untuk melakukan interaksi dan transaksi pihak bank. Salah satu dari layanan e-banking itu adalah Mobile Banking Bank Negara Indonesia(Persero)Tbk. Dengan adanya Mobile Banking maka nasabah PT Bank Negara Indonesia(Persero)Tbk. Cabang Mamuju tidak perlu datang ke Bank atau mesin ATM untuk melakukan transaksi. Transaksi transfer, mengecek saldo, pembayaran telepon atau listrik maupun produk lainnya yang ditawarkan bank dapat dilakukan melalui mobile banking. PT. Bank Negara Indonesia(Persero)Tbk. Cabang Mamuju, akan memberikan manfaat bagi bank dan nasabahnya. Dengan menggunakan mobile banking, bank dapat memberikan kemudahan bertransaksi yang mana dapat menumbuhkan kepuasan dalam diri nasabah tersebut.

\section{Rumusan Masalah}

Berdasarkan latar belakang yang diuraikan di atas, maka penulis merumuskan masalah sebagai berikut :

1. Apakah penggunaan Mobile Banking melalui smartphone berpengaruh secara simultan terhadap kepuasan nasabah?

2. Apakah penggunaan Mobile Banking melalui smartphone berpengaruh secara Parsial terhadap kepuasan nasabah?

3. Variabel manakah dari penggunaan Mobile Banking yang paling dominan berpengaruh terhadap kepuasan nasabah?

\section{Tujuan Penelitian}

1. Untuk mengetahui pengaruh variabel penggunaan Mobile Banking secara simultan dan parsial terhadap kepuasan nasabah.

2. Untuk mengetahui variabel yang paling dominan dari penggunaan Mobile banking terhadap kepuasan nasabah.

\section{Manfaat Penelitian}

Hasil penelitian ini diharapkan dapat memberikan manfaat bagi :

1. Bagi perusahaan, sebagai sumbangan pemikiran untuk mengetahui sejauh mana penggunaan Mobile banking dapat memudahkan bagi nasabah dalam bertransaksi. 
2. Sebagai bahan referensi sekaligus sebagai bahan banding bagi peneliti yang relevan.

\section{LANDASAN TEORI}

\section{Pengertian Sistem Informasi}

Pengertian Sistem Informasi

Sistem informasi dapat merupakan kombinasi teratur apapun dari orangorang, hardware, software, jaringan komunikasi dan sumber daya data yang dikumpulkan. Orang bergantung pada sistem informasi untuk berkomunikasi antara satu sama lain dengan menggunakan berbagai jenis alat fisik (hardware), perintah dan prosedur pemrosesan informasi (software), saluran komunikasi (jaringan), dan data yang disimpan (O'Brien, 2005:5).

Sistem informasi dapat juga didefinisikan secara teknis sebagai satuan komponen yang saling berhubungan yang mengumpulkan (atau mendapatkan kembali), memproses, menyimpan, dan mendistribusikan informasi untuk mendukung pengambilan keputusan dan kendali dalam organisasi (Laudon \& Laudon, 2005:9). Davis dan Leitch dalam Jogiyanto (2002:11) menyebutkan bahwa sistem informasi adalah suatu sistem di dalam suatu organisasi yang mempertemukan kebutuhan pengolahan transaksi harian, mendukung operasi, bersifat manajerial dan kegiatan strategi dari suatu organisasi dan menyediakan pihak luar tertentu dengan laporanlaporan yang diperlukan. Dari beberapa definisi di atas dapat disimpulkan bahwa sistem informasi adalah kerangka kerja yang mengkoordinasikan sumber daya (manusia dan komputer) untuk mengubah masukan (input) menjadi keluaran (informasi) guna mencapai sasaran-sasaran perusahaan. Sistem Informasi bertujuan untuk menghasilkan Informasi. Informasi adalah data yang diolah menjadi bentuk yang berguna bagi para pemakainya.

\section{Pengertian Teknologi informasi}

Teknologi Informasi adalah sub-sistem atau sistem bagian dari sistem informasi (Jogiyanto, 2005:3). Pengertian yang lebih detail diberikan oleh Wawan Wardiana (2002) yang menyatakan bahwa: "Teknologi Informasi adalah suatu teknologi yang digunakan untuk mengolah data, termasuk memproses, mendapatkan, menyusun, menyimpan, memanipulasi data dalam berbagai cara untuk menghasilkan informasi yang berkualitas, yaitu informasi yang relevan, akurat dan tepat waktu, yang digunakan untuk keperluan pribadi, bisnis, dan pemerintahan dan merupakan informasi yang strategis untuk pengambilan keputusan".

$$
\text { Teknologi }
$$

informasi memainkan peranan penting dalam perekayasaan ulang sebagian besar proses bisnis. Kecepatan, kemampuan pemrosesan informasi dan konektivitas komputer serta teknologi Internet dapat secara mendasar meningkatkan efisiensi proses bisnis, seperti juga meningkatkan komunikasi dan kerja sama antar orang-orang yang bertanggung jawab atas operasi dan manajemennya (O'Brien, 2005:76). Lebih lanjut mengenai teknologi informasi di www.slu.edu (diakses 3 Mei 2012) dijelaskan sebagai "The creation, gathering, processing, strorage and devices that make it all possible". Dengan demikian dapat disimpulkan bahwa teknologi informasi adalah penerapan pengetahuan untuk suatu tujuan tertentu berkenaan dengan pemanfaatan informasi. Namun demikian tentu saja penggunaan suatu teknologi informasi ini disesuaikan 
dengan kebutuhan dan kemampuan individu atau organisasi.

\section{Mobile Banking}

Pada kenyataannya, internet saat ini bukan hanya sebagai alat komunikasi semata, namun fungsi dari internet semakin meluas dan menjadi alternatif yang cukup inovatif untuk semakin memajukan berbagai komponen bisnis yang ada. Tidak ketinggalan juga dunia perbankan kini telah memilih internet sebagai alat transaksi bagi masyarakat, yang saat ini populer disebut Mobile banking. Mobile banking adalah salah satu komponen e-banking yang mudah, menyenangkan dan aman.

Menurut Center For Regulatory Research / CFRR (2003) definisi dari Mobile banking adalah : Penggunaan internet dengan smartphone sebagai jalur pengiriman jarak jauh untuk pelayanan tradisional, seperti pembukaan rekening deposito atau pengiriman dana pada rekening yang berbeda, sebagaimana pelayanan perbankan baru baru ini seperti pengiriman dan pembayaran tagihan elektronik yang memperkenankan nasabah untuk menerima dan membayar tagihan melalui $\mathrm{Hp}$ Smartphone tersebut. Jadi, Mobile banking adalah suatu aktivitas perbankan yang menggunakan Smartphone yang dilengkapi dengan data internet sebagai sarana untuk melakukan transaksi antara nasabah dengan suatu bank. Untuk dapat menggunakan layanan ini, seorang nasabah akan dibekali dengan login di Aplikasi Mobile Banking yang sebelumnya sudah didownload lewat aplikasi Palystore. (Kompas Cyber Media, 2003). Mobile Banking BNI adalah fasilitas layanan yang diberikan kepada nasabah untuk melakukan transaksi perbankan melalui layanan akses internet paket data pada HP Smartphone, seperti: - Cek Saldo •
Mutasi Rekening - Transfer Antar Rekening - Pembayaran Tagihan: Kartu Kredit, KTA, PLN, dan TELKOM, Pembelian pulsa dll.

\section{Dimensi Yang Mempengaruhi Nasabah Menggunakan Mobile Banking}

Layanan Mobile Banking Smartphone dapat dilakukan dimana saja dan kapan saja selama pengguna Mobile banking memiliki sarana internet untuk dapat berkomunikasi dengan pihak bank. Kelebihan dari fasilitas ini adalah nasabah dapat mengakses rekening 24 jam sehari dalam 7 hari seminggu. Raed Awamleh dan Cedwyn Fernandes dari University of Wollongong In Dubai (2005) melakukan penelitian terhadap mobile banking smartphone, untuk mengidentifikasi dimensi-dimensi penentu kepuasan nasabah dalam menggunakan Mobile Banking. Dalam penelitian tersebut Raed Awamleh dan Cedwyn Fernandes (2005) mengemukakan adanya tiga dimensi yang menyebabkan nasabah menggunakan Mobile Banking, yaitu :

1. Independence (Kebebasan) Nasabah bank dapat berinteraksi dengan bank tanpa harus berhubungan langsung dengan karyawan bank. Hal ini sangat berguna untuk mengurangi kekeliruan dalam berkomunikasi.

2. Convenience (Kesenangan) Kenyamanan pada sisi lain dapat menggambarkan kesenangan seseorang untuk menggunakan layanan ini. Nasabah dapat menggunakan jasa perbankan ini dimana saja dan kapan saja selama 24 jam non-stop.

3. Security (Keamanan) Keamanan mengukur persepsi nasabah mengenai keselamatan dan keandalan layanan perbankan ini. Dalam hal ini penyedia Internet Banking menjamin resiko yang 
lebih kecil dari pada harus datang langsung ke bank yang bersangkutan untuk melakukan transaksi.

Masalah keamanan menjadi dimensi yang mempengaruhi nasabah menggunakan mobile banking, dengan layanan Mobile banking akan meminimalisir resiko yang ditimbulkan dari pada langsung ke bank yang bersangkutan untuk melakukan transaksi. Namun, keamanan dalam melakukan transaksi pada mobile banking bukanlah sepenuhnya tanggung jawab pihak bank. Nasabah pun dituntut berperan aktif menjaganya (www.kompas.com / diakses tanggal 3 Mei 2012).

\section{Kepuasan Nasabah}

Kepuasan nasabah menjadi faktor yang menentukan keberhasilan bank dalam menjalankan usahanya. Bagi bank yang berorientasi jangka panjang, kepuasan nasabah harus dijadikan salah satu tujuan dari strategi perusahaan. Hal ini dikarenakan persepsi nasabah menentukan apakah nasabah tersebut akan tetap menggunakan produk atau jasa bank atau beralih pada bank lain dan secara tidak langsung meragukan kredibilitas bank sebelumnya. Hal ini akan menimbulkan citra yang tidak baik dalam masyarakat sehingga dapat pula dikatakan bahwa kepuasan nasabah juga berdampak pada kelangsungan hidup bank itu sendiri.

\section{Model Konsep dan Hipotesis}

\section{Model Konsep}

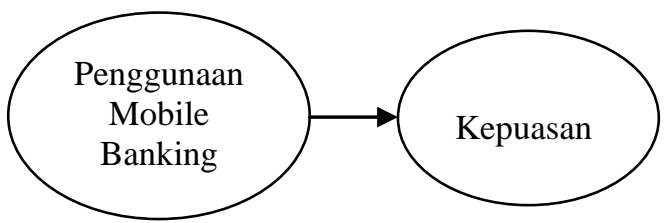

Gambar 1. Model Konsep

\section{Hipotesis}

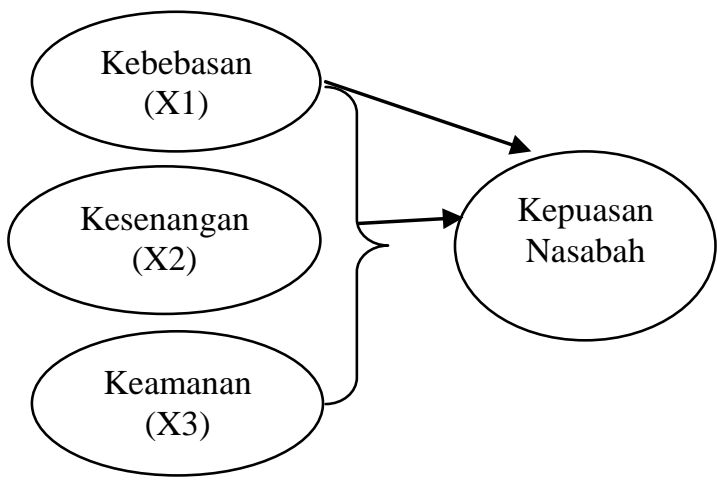

Gambar 2. Hipotesis

$\begin{aligned} \mathrm{H} 1= & \begin{array}{l}\text { Diduga penggunaan mobile } \\ \text { banking }\end{array} \text { smartphone yang }\end{aligned}$ terdiri dari kebebasan, kesenangan dan keamanan secara simultan berpengaruh signifikan terhadap kepuasan nasabah.

$\mathrm{H} 2=$ Diduga penggunaan mobile banking yang terdiri dari kebebasan, kesenangan dan keamanan secara parsial berpengaruh signifikan terhadap kepuasan nasabah.

\section{METODE PENELITIAN}

Penelitian ini dilaksanakan pada PT. Bank Negara Indonesia (Persero) Cabang Mamuju. Penelitian ini dilakukan dengan cara pengambilan sampel dari suatu populasi dan menggunakan kuesioner sebagai alat pengumpul data yang pokok, untuk menjelaskan hubungan kausal antara variabel-variabel. Sehingga penelitian ini menggunakan pendekatan kuantitatif dengan jenis penelitian (explanatory) penjelasan. Jumlah sampel yang akan diambil berjumlah 100 responden.

Teknik pengambilan sampel dalam penelitian ini menggunakan teknik aksidental. Pada penelitian ini Analisis data yang dilakukan dengan tahapan sebagai berikut: 


\section{Analisis deskriptif}

Analisis ini digunakan untuk mendeskripsikan karakteristik daerah penelitian, keadaan responden yang diteliti dan distribusi item masingmasing variabel. Data yang terkumpul ditabulasikan dalam tabel dan dibahas secara deskriptif dalam angka dan persentase.

\section{Uji Asumsi Klasik}

Untuk memperoleh nilai pemerkira yang tidak bias dan efisien dari suatu persamaan regresi berganda dengan metode kuadrat terkecil (OLS), maka dalam pelaksanaan analisa data harus memenuhi asumsi-asumsi klasik sebagai berikut : normalitas, autokorelasi, Heteroskedastisitas, Multikolinieritas

\section{Analisis Regresi Berganda}

Digunakan untuk mengetahui pengaruh antara beberapa variabel bebas secara bersamaan dengan satu variabel terikatnya.

\section{HASIL PENELITIAN DAN PEMBAHASAN}

\section{Analisis Regresi Linear Berganda}

Analisis regresi linear berganda digunakan untuk mengetahui besarnya pengaruh dari variabel Kebebasan (X1) dan Kesenangan (X2) terhadap Kepuasan nasabah (Y). Hasil perhitungan dengan menggunakan program SPSS Versi 15.0 For windows dapat dilihat pada tabel berikut :

\begin{tabular}{|c|c|c|l|c|}
\hline $\begin{array}{c}\text { Varia } \\
\text { bel }\end{array}$ & Keterangan & $\begin{array}{c}\text { Koefisi } \\
\text { en } \\
\text { Regresi }\end{array}$ & $\begin{array}{l}\mathrm{t} \\
\text { hitung }\end{array}$ & Sig \\
\hline $\mathrm{X} 1$ & Kebebasan & 0,330 & 5,639 & 0,000 \\
$\mathrm{X} 2$ & Kesenangan & 0,206 & 5,209 & 0,000 \\
$\mathrm{X} 3$ & Keamanan & 0,239 & 5,377 & 0,000 \\
\hline \hline Konstanta & 0,978 \\
$\mathrm{R}$ & 0,841 \\
$\mathrm{R}$ square & 0,698 \\
Fhitung & 76,379 \\
Sig. F & 0,000 \\
$\mathrm{n}$ & 99 \\
\hline \multicolumn{4}{|l}{ Variabel terikat $=$ Kepuasan nasabah (Y). } \\
\hline
\end{tabular}

Sumber : Data primer diolah, 2019.
Penggunaan Mobile Banking

Hasil perhitungan regresi berganda tersebut dapat diketahui formulasinya sebagai berikut : $\mathrm{Y}=$ $0,978+0,330 \mathrm{X} 1+0,206 \mathrm{X} 2+$ 0,239X3 Berdasarkan hasil persamaan tersebut, maka dapat dijelaskan sebagai berikut :

a. Konstanta (b0) = 0,978 menunjukkan besarnya kepuasan nasabah (Y), jika tidak ada kebebasan, kesenangan dan keamanan, maka besarnya kepuasan nasabah (Y) sebesar 0,978 .

b. Koefisien regresi X1 (Kebebasan) sebesar 0,330 (b1), menunjukkan besarnya pengaruh X1 (Kebebasan) terhadap kepuasan nasabah (Y), koefisien regresi bertanda positif menunjukkan X1 (Kebebasan) berpengaruh searah terhadap Kepuasan nasabah (Y), yang berarti semakin baik Kebebasan (X1) yang diberikan perusahaan akan menyebabkan peningkatan kepuasan nasabah (Y).

c. Koefisien regresi X2 (Kesenangan) sebesar 0,206 (b2), menunjukkan besarnya pengaruh X2 (Kesenangan) terhadap kepuasan nasabah (Y), koefisien regresi bertanda positif menunjukkan X2 (Kesenangan) berpengaruh searah terhadap kepuasan nasabah (Y), yang berarti semakin baik kesenangan (X2) akan menyebabkan peningkatan kepuasan nasabah (Y).

d. Koefisien regresi X3 (Keamanan) sebesar 0,239 (b3), menunjukkan besarnya pengaruh X3 (Keamanan) terhadap kepuasan nasabah (Y), koefisien regresi bertanda positif menunjukkan X3 (Keamanan) berpengaruh searah terhadap kepuasan nasabah $(\mathrm{Y})$, yang berarti semakin baik keamanan (X3) akan menyebabkan kepuasan nasabah (Y). 
Koefisien korelasi berganda (R) sebesar 0,841 ; menunjukkan bahwa secara bersama-sama terdapat hubungan yang sangat kuat dan searah antara kebebasan, kesenangan dan keamanan dengan kepuasan nasabah (Y) sebesar $84,1 \%$. Hubungan ini dapat dikategorikan sangat kuat, sebagaimana diketahui bahwa suatu hubungan dikatakan sempurna jika koefisien korelasinya mencapai angka $100 \%$ atau 1 (baik dengan angka positif atau negatif).

Dari hasil analisa regresi linier berganda di atas, dapat diketahui nilai koefisien determinasi (adjusted $\mathrm{R}$ square) sebesar 0,698. Angka ini menunjukkan bahwa variabel kebebasan, kesenangan dan keamanan dapat menjelaskan variasi atau mampu memberikan kontribusi terhadap variabel kepuasan nasabah (Y) sebesar $69,8 \%$, sedangkan sisanya sebesar $30,2 \%$ disebabkan oleh variabel lain yang tidak dimasukkan dalam penelitian.

\section{Uji Hipotesis 1}

Untuk menguji
hipotesis pertama yang menyatakan bahwa variabel penggunaan internet banking yang terdiri dari kebebasan, kesenangan dan keamanan secara simultan berpengaruh signifikan terhadap kepuasan nasabah, menggunakan uji F. Uji $F$ digunakan untuk mengetahui signifikansi pengaruh variabel penggunaan internet banking yang terdiri dari kebebasan, kesenangan dan keamanan secara simultan mempunyai pengaruh signifikan terhadap kepuasan nasabah. Apabila besarnya Fhitung > Ftabel atau nilai signifikansi $<0,05$, maka Ho ditolak dan $\mathrm{Ha}$ diterima. Dari hasil perhitungan analisa regresi berganda dengan SPSS Versi 15.0 For windows diperoleh Fhitung sebesar 76,379, sedangkan Ftabel pada $\square=5 \%$, df1 $=$
3 , dan df $2=95$ sebesar 2,70; hal ini berarti Fhitung $>$ Ftabel $(76,379>2,70)$ sedangkan nilai probabilitasnya lebih kecil dari $\square=0,05(0,000<0,05)$, maka Ho ditolak dan Ha diterima yang berarti bahwa variabel penggunaan internet banking yang terdiri dari kebebasan, kesenangan dan keamanan secara simultan berpengaruh signifikan terhadap kepuasan nasabah, dengan demikian hipotesis pertama secara statistik dapat diterima atau teruji.

\section{Uji Hipotesis 2}

Untuk menguji hipotesis kedua yang menyatakan bahwa penggunaan internet banking yang terdiri dari kebebasan, kesenangan dan keamanan secara parsial berpengaruh signifikan terhadap kepuasan nasabah, menggunakan uji t. Adapun hasil analisis uji $\mathrm{t}$ disajikan pada tabel berikut.

Tabel 2. Perbandingan thitung dan

ttabel $\square=5 \%$

Koefisien thitung

\begin{tabular}{|l|l|l|l|} 
thitung & ttabel & Sig. & Keterangan \\
\hline
\end{tabular}

\begin{tabular}{|l|l|l|l|l|}
\hline 0,206 & 5,209 & 2,000 & 0,000 & Signifikan \\
\hline
\end{tabular}

0,239

5,377

\begin{tabular}{|l|l|l|}
\hline 2,000 & 0,000 & Signifikan \\
\hline
\end{tabular}

Sumber : Data primer diolah, 2019.

Berdasarkan hasil uji $t$ diperoleh nilai thitung variabel kebebasan sebesar 5,639 sedangkan nilai ttabel $=2,000$ sehingga thitung $>$ ttabel atau nilai signifikansi $0,000<$ 0,05 jadi Ho ditolak atau Ha diterima, sehingga variabel kebebasan berpengaruh signifikan terhadap kepuasan nasabah (Y).

Nilai thitung variabel kesenangan sebesar 5,209 sedangkan nilai ttabel $=2,000$ sehingga thitung > ttabel atau nilai signifikansi $0,000<$ 0,05 jadi Ho ditolak atau Ha diterima, sehingga variabel kesenangan 
berpengaruh signifikan terhadap kepuasan nasabah (Y).

Nilai thitung variabel keamanan sebesar 5,37 sedangkan nilai ttabel $=2,000$ sehingga thitung $>$ ttabel atau nilai signifikansi $0,000<0,05$ jadi Ho ditolak atau Ha diterima, sehingga variabel keamanan berpengaruh signifikan terhadap kepuasan nasabah (Y).

\section{Pengaruh Kebebasan terhadap Kepuasan Nasabah}

Kebebasan

berpengaruh

signifikan terhadap kepuasan nasabah dan merupakan variabel yang berpengaruh dominan terhadap kepuasan nasabah. Hasil penelitian ini konsisten dengan penelitian Setiawan (2006) dan Wicaksana (2007) yang menyatakan bahwa convidence berpengaruh signifikan terhadap kepuasan nasabah. Hasil ini didukung dari jawaban responden yang menyatakan cenderung setuju bahwa nasabah mendapatkan privasi dalam menggunakan mobile banking smartphone, dapat mencari dengan mudah apa yang ingin saya kerjakan di mobile banking smartphone, Mobile Banking smartphone memudahkan saya dalam bertransaksi, Internet Banking memudahkan saya berinteraksi dengan bank, Mobile Banking mempercepat transaksi perbankan, dan Mobile Banking dapat digunakan untuk transaksi perbankan yang tersedia. Hal ini menunjukkan bahwa nasabah bebas dalam mengakses mobile banking, Mobile banking merupakan suatu sistem yang memungkinkan nasabah bank untuk mengakses rekening dan informasi umum produk dan jasa suatu bank melalui smartphone. Umumnya transaksi ini meliputi pengecekan rekening, mengamati daftar transaksi yang menggunakan rekening, dan mentransfer dana dari satu rekening online ke rekening lainnya. Hal ini didukung pendapat Sedangkan keuntungan mobile banking bagi nasabah menurut Nath et al (2000) adalah :

1. Penghematan Biaya (Cost Savings) Struktur biaya mobile banking memungkinkan konsumen untuk mendapatkan penurunan biaya karena perbankan yang online.

2. Akses Pada Layanan Tambahan (Access to Additional Services) Situs mobile banking memungkinkan nasabah untuk mereview neraca rekening, juga memungkinkan nasabah untuk membayar tagihan, meminta review pinjaman atau hipotek dan mengecek tagihan kartu kredit. Konsumen akan mendapat keuntungan dari banyaknya pilihan jasa yang tersedia dari institusi yang terpercaya.

3. One Stop Shopping yang mudah bank dapat menambahkan aplikasiaplikasi pinjaman realtime, kesempatan untuk memperdagangkan saham melalui website mereka. Konsep "one stop" shopping adalah cocok dan akan memberikan kepuasan yang lebih besar kepada konsumen.

\section{Pengaruh Kesenangan terhadap Kepuasan Nasabah}

Kesenangan berpengaruh signifikan terhadap kepuasan nasabah. Hasil penelitian ini konsisten dengan penelitian Setiawan (2006) dan Wicaksana (2007) yang menyatakan bahwa convenience berpengaruh signifikan terhadap kepuasan nasabah. Hasil ini didukung dari jawaban responden yang menyatakan cenderung setuju bahwa Mobile Banking Smartphone dapat digunakan dimana saja, Mobile Banking dapat digunakan kapan saja, Mobile Banking menghemat waktu yang digunakan untuk bertransaksi daripada harus datang ke Bank atau mesin ATM, dan Biaya yang saya gunakan untuk menggunakan 
Mobile banking relatif rendah. Hal ini menunjukkan bahwa nasabah tidak perlu lagi membuang waktu untuk antri di kantor-kantor bank atau ATM, karena saat ini banyak transaksi perbankan dapat dilakukan dimanapun dan kapanpun dengan mudah dan praktis melalui jaringan elektronik seperti data internet dan HP Smartphone.

\section{Pengaruh Keamanan terhadap Kepuasan Nasabah}

Keamanan berpengaruh signifikan terhadap kepuasan nasabah. Hasil penelitian ini konsisten dengan penelitian Setiawan (2006) dan Wicaksana (2007) yang menyatakan bahwa security berpengaruh signifikan terhadap kepuasan nasabah. Hasil ini didukung dari jawaban responden yang menyatakan cenderung setuju bahwa nasabah yakin sistem mobile banking mampu melindungi transaksi, Informasi yang didapatkan dalam mobile banking selalu tepat, Mobile Banking mampu menjamin keamanan keuangan dan nasabah yakin bahwa data yang ada di dalam mobile banking sama atau terintegrasi dengan data pada bank. Hal ini menunjukkan bahwa keamanan menjadi dimensi yang mempengaruhi nasabah menggunakan mobile banking, dengan layanan mobile banking akan meminimalisir resiko yang ditimbulkan dari pada langsung ke bank yang bersangkutan untuk melakukan transaksi. Namun, keamanan dalam melakukan transaksi pada mobile banking bukanlah sepenuhnya tanggung jawab pihak bank. Nasabah pun dituntut berperan aktif menjaganya (www.kompas.com / diakses tanggal 3 Mei 2012). Hal ini sesuai dengan pendapat Nath et.al (2000), mengemukakan bahwa umumnya mobile banking menggunakan beberapa sistem yang melindungi informasi rekening dan data nasabah, yaitu :
1. User ID dan PIN (Personal Identification Number), merupakan kode rahasia dan kewenangan pengguna yang diberikan kepada nasabah, yaitu setiap kali login ke mobile banking.

2. Automatic Log Out, jika tidak ada tindakan yang dilakukan lebih dari 10 menit, mobile banking secara otomatis akan mengakhiri dan kembali ke menu utama.

3. SSL, 128-Bit Encryption, seluruh data di mobile banking dikirimkan melalui protokol Secure Socket Layer (SSL), yaitu suatu standar pengiriman data rahasia melalui internet. Protokol SSL ini akan mengacak data yang dikirimkan menjadi kode-kode rahasia dengan menggunakan 128-bit encryption, yang artinya terdapat 2 pangkat 128 kombinasi angka kunci,tetapi hanya satu kombinasi yang dapat membuka kode-kode tersebut.

4. Firewall, untuk membatasi dan menjamin hanya nasabah yang mempunyai akses untuk dapat masuk ke sistem mobile banking.

\section{KESIMPULAN DAN SARAN}

\section{Kesimpulan}

Berdasarkan hasil deskriptif statistik menunjukkan bahwa rata-rata skor kebebasan sebesar 4,09 yang berarti bahwa nasabah dapat bebas berinteraksi langsung bank tanpa harus datang langsung ke bank yang bersangkutan, sehingga memudahkan nasabah untuk melakukan transaksi dengan pihak bank. Rata-rata skor kesenangan sebesar 3,97 yang bermakna bahwa penggunaan mobile banking merupakan hal yang menyenangkan bagi nasabah. Rata-rata skor keamanan sebesar 4,12, yang bermakna bahwa PT. Bank Negara Indonesia (Persero) Tbk penyedia aplikasi mobile banking menjamin keamanan dalam bertransaksi karena 
memiliki teknologi yang dipercaya dan sistem yang baik. Sedangkan variabel kepuasan nasabah memiliki nilai skor rata-rata sebesar 4,14 , yang bermakna bahwa responden merasa puas dengan layanan mobile banking.

Kebebasan, kesenangan dan keamanan secara simultan berpengaruh signifikan terhadap kepuasan nasabah. Hal ini berdasarkan hasil perhitungan analisa regresi berganda Fhitung > Ftabel $(76,379>2,70)$ sedangkan nilai probabilitasnya lebih kecil dari $\square=$ $0,05(0,000<0,05)$. Sedangkan nilai koefisien determinasi ( $\mathrm{R}$ square) sebesar 0,698. Angka ini menunjukkan bahwa variabel kebebasan, kesenangan dan keamanan dapat menjelaskan variasi atau mampu memberikan kontribusi terhadap variabel kepuasan nasabah sebesar $69,8 \%$. Kebebasan, kesenangan dan keamanan secara parsial berpengaruh signifikan terhadap kepuasan nasabah, dibuktikan dengan nilai-nilai signifikansi lebih kecil dari $\square=0,05(0,000<0,05)$.

\section{Saran}

Dalam upaya meningkatkan kepuasan nasabah mobile banking, maka langkah yang dapat ditempuh oleh pimpinan bank adalah melalui peningkatan kualitas sistem informasi. Bagi peneliti lain yang berminat melakukan kajian ulang terhadap penelitian ini, diharapkan dapat melakukan pengembangan dan perbaikan terhadap penelitian ini. Perbaikan dan pengembangan tersebut dapat dilakukan melalui: penambahan beberapa variabel lain yang secara teoritis dapat mempengaruhi kepuasan nasabah, serta menggunakan responden yang lebih banyak. Dengan perbaikan dan pengembangan tersebut diharapkan hasil penelitiannya akan lebih baik dan bermanfaat.

\section{DAFTAR PUSTAKA}

Awamleh, R and Fernandes. 2005, Pengaruh Penggunaan Electronic Banking Terhadap Kepuasan Nasabah" studi pada pengguna internet banking PT. Bank Z (Persero) Tbk Cabang Malang.

Jogiyanto H.M. 2005. Sistem Teknologi Informasi. Yogyakarta : Andi Offset. 2005.

Journal of Internet Banking and Commerce, Internet Banking : An emprical investigation into the extent of adoption by banks and the determinants of customer satisfaction in the United Arab Emirates.

Laudon, Kenneth C, dan Jane P. Laudon. 2005. Analisis dan Desain Sistem Informasi : Pendekatan Terstruktur Teori dan Praktek Aplikasi Bisnis. Yogyakarta : Andi Offset.

O'Brien, James A. 2005. Sistem Informasi Manajemen

Mengelola Perusahaan Digital. Yogyakarta : Penerbit Andi Offset. O'Brien, James A. 2005.

Setiawan, Doni. 2006, Pengantar Sistem Informasi Perspektif Bisnis dan Manajerial. Jakarta : Salemba Empat. Setiawan, Doni. 2006.

Wardiana, Wawan. 2002. Pengaruh Internet Banking Terhadap Kepuasan Nasabah" studi pada nasabah Bank Central Asia, Malang.

Wicaksana, Arif, T. 2007, Perkembangan Teknologi Informasi di Indonesia, Jurnal Teknologi Informasi. 